COGNITION, RESOURCES,

AND INSTITUTIONS IN

THE EXPLANATION OF

ATTITUDES TO FREE

TRADE

Juan Díez Medrano \& Michael Braun

$2009 / 23$

\begin{tabular}{|c|c|}
\hline & \multicolumn{1}{|c}{} \\
\hline I & $B$ \\
\hline$E$ & 1 \\
\hline
\end{tabular}

INSTITUT

BARCELONA

INTERESTCLDIINALS

Juan Díez Medrano

Institut Barcelona d'Estudis Internacionals

Universitat de Barcelona

jdiez@ibei.org

Michael Braun

Leibniz Institute for the Social Sciences, Mannheim

michael.braun@gesis.org 


\section{IBEI WORKING PAPERS}

$2009 / 23$

Cognition, Resources, and Institutions in the Explanation of Attitudes to Free Trade

(C) Juan Díez Medrano \& Michael Braun

(C) IBEI, de esta edición

$\begin{array}{ll}\text { Edita: } & \text { CIDOB edicions } \\ & \text { Elisabets, } 12 \\ & 08001 \text { Barcelona } \\ & \text { Tel. } 933026495 \\ & \text { Fax. } 933022118 \\ & \text { E-mail: publicaciones@cidob.org } \\ & \text { URL: www.cidob.org }\end{array}$

Depósito legal: B-21.147-2006

ISSN:1886-2802

Imprime: Color Marfil, S.L.

Barcelona, September 2009 


\title{
COGNITION, RESOURCES, AND INSTITUTIONS IN THE EXPLANATION OF ATTITUDES TO FREE TRADE
}

\author{
Juan Díez Medrano \& Michael Braun
}

\begin{abstract}
This article proposes a framework for the analysis of attitudes to foreign trade policies that challenges the traditional skill-endowment approach. The traditional approach assumes informed individuals who calculate the costs and benefits of alternative policies. We propose that individuals lack information and that their positions rest on economic vulnerability, as mediated through risk-aversion. We also stress the role of environmental signals and political endorsements in guiding individuals' views on trade policy. We test this alternative approach with a Spanish survey conducted in May 2009 and the ISSP survey conducted in 2003 in a large number of less developed and more developed countries. The Spanish data show that the population is largely uninformed and that their ideas about the consequences of free trade policy do not explain attitudes among different socio-demographic groups. Meanwhile, the ISSP data contradict important aspects of the traditional approach and are consistent with the alternative approach.
\end{abstract}

Key words: Institutions, Cognition, Free Trade, Attitudes, Globalization 


\section{Introduction}

The expected-utility model of choice under uncertainty that once dominated the science of economics has been debated and challenged for more than half a century (Machina 1987, 1989). While the theory has proven to be flexible and extremely capable of integrating anomalies, other alternative theoretical approaches have provided legitimate alternatives to the standard approach to the study of choice. In particular these approaches have introduced the concept of bounded rationality, which they have successfully applied to the study of choice in situations where actors have very little or no information about the probabilities of alternative outcomes (March 1994; Simon 1991; Kahneman 2003; Conlisk 1996). ${ }^{1}$ This article applies concepts derived from this and the economic sociology literatures, such as limited information, frames, and embeddedness, to the study of attitudes toward free trade, where their explanatory potential has barely been explored. ${ }^{2}$ Our goals are to recast the study of this important topic in a way that is more realistic and to re-evaluate through replication previous and new findings in light of this alternative approach.

The liberalization of trade in goods, capital, and services has played a major role in the transformation of the world economy of the past twenty-five years. There have been winners and losers in the first, second, and third worlds alike, depending on ability to compete in this global field. Not surprisingly then, social movements and political parties have emerged that oppose free trade. More recently, the 2009 financial and economic crisis has prompted many governments to call for and sometimes even approve protectionist policies. Although attitudes in the population usually play a secondary role in shaping trade policy, they sometimes have significant political ramifications (e.g. support for political parties that oppose free trade agreements, illustrated by support for Ross Perot in the early 90s or the French population's rejection of the European Union Constitution in 2005). This article addresses the question of whether public opinion attitudes to free trade follows the logic sketched out by most economists and political economists who have approached the topic or whether they obey an alternative economic logic instead. The puzzle that raised our interest in the issue of attitudes to trade policy was the empirical observation of a negative relationship between people's skill levels and protectionism in poor countries, where the application of standard factor-endowment international trade theory to the study of attitudes to trade policy would predict this relationship to be positive ( $\mathrm{O}^{\prime}$ Rourke and Sinnott 2001). Only recently have researchers expressed interest in this puzzle (Beaulieu, Benarroch, and Gaisford 2004; Baker 2005). The literature offers other puzzles as well, however, like extant models' extremely low explanatory power and the high percentages of non-response or 'don't know' answers for survey questions relative to trade policy. We argue that these puzzles are related and that they reveal the problematic character of the premises on which these models are built.

Machina (1989) sees the impact of frames on behavior as one of the thorniest issues for the expected utility model.

The most notable exceptions being Hainmueller and Hiscox 2005 and Hiscox 2006. 
The economic and political economy literatures on the topic of attitudes toward free trade assume that individuals are well-informed about the impact of free trade policies on their economic well-being and that they choose one or another policy based on cost-benefit calculations. ${ }^{3}$ When faced with contradictory empirical findings, the researchers' reaction has been to refine the assessment of the distributional economic effects of free trade policy rather than question the cognitive premises underlying these models. This article shows that while previous statistical findings concerning actual empirical relationships are robust and can be replicated, the explanatory model used to account for them is wanting. In contrast to standard approaches, we propose that people's attitudes to trade policy reflect an economic rationality that rests on lack of information and on internalized risk-aversion. Based on these alternative premises, we hypothesize that individual support for free trade mainly depends on how survey questions are framed, on the individuals' perceived degree of economic vulnerability, and on political and institutional endorsements.

The data for our statistical analysis come from two sources: First, a nationally representative survey conducted in Spain in 2009 helps us determine how realistic traditional models are. To our knowledge, this is the first test of the cognitive mechanisms allegedly mediating the relationship between socio-demographic characteristics and attitudes toward alternative trade policies. The second source for our empirical analysis is the ISSP international public opinion survey conducted in 2003. Data from 32 countries allow us to test individual-level and aggregate-level hypotheses derived from competing analytical and theoretical approaches, including ours. One significant advantage of the 2003 ISSP over a previous ISSP survey conducted in 1995, on which most of the empirical literature on attitudes to free trade relies, is that it includes many more countries and a wider range of economic development levels.

\section{The Full-Information Factor Endowment Approach to Attitudes to Free Trade}

The literature has mainly emphasized the role of relative opportunities in explaining attitudes to free trade. The dominant version of what one could call a full-information, factor endowment approach links the individuals' main economic activities, and the skills tied to these activities, to their net benefit calculations and, from there, to their attitudes to free trade. The Stolper-Samuelson theorem and the Heckscher-Ohlin model (1933) predict that free trade benefits the relatively

\footnotetext{
Scheve and Slaughter 2001, p. 272: "In the literature on the political economy of trade policy, it is commonly assumed that individuals evaluate trade policy based on how their current factor incomes are affected, without regard for aggregate national welfare"; Rankin 2002, p. 353: "The economic selfinterest perspective assumes that citizens understand the costs and benefits of policy to their material self-interest..."
} 
most abundant labor factor in a given country (Stolper and Samuelson 1941). Skilled workers should thus benefit more from free trade in rich than in poor countries, whereas the reverse is true for non-skilled workers. Scholars have used this reasoning to hypothesize that ceteris paribus skilled workers are more supportive of free trade in advanced economies than in less advanced ones whereas non-skilled workers are more supportive of free trade in less advanced economies than in advanced economies (Scheve and Slaughter 2001; Mayda and Rodrik 2005; O'Rourke and Sinnott 2001). Another, more complex, version of the factor endowment approach has drawn on the Ricardo-Viner framework for the analysis of effects of free trade on labor and hypothesized that support for free trade depends on the comparative advantage of the industries where individuals work (Irwin 1994; Magee 1980). Finally, some authors within the factor endowment approach have emphasized the role of people's interpretation of signals picked up from their environment. Their claim is that people interpret macroeconomic data as revealing the benefits and disadvantages of trade policy.

Although authors have interpreted empirical results as supporting the StolperSamuelson, Heckscher-Ohlin version of the factor endowment model, the truth is that, in Kuhnian fashion (Kuhn 1962), they have been blind to evidence that contradicts it. In particular, with only a few recent exceptions (Beaulieu et al. 2004; Baker 2005), they have ignored the statistical finding that, contrary to what the model predicts, in less developed countries skilled workers (the factor in short supply) are as or less protectionist than non-skilled workers (the abundant factor). ${ }^{4}$

In an effort to rescue the traditional approach, Baker has recently shifted our attention from the individual as producer to the individual as consumer. His argument reads as follows: "Stated generally, holding skill level constant, heavy consumers of goods that are intensive in their country's abundant factor undergo relative real wage (i.e. purchasing power) losses from trade liberalization compared to heavy consumers of the scarce-factor-intensive-good. Therefore, the propensity to consume skill-intensive goods should be negatively correlated with support for free trade in skill-abundant countries and positively associated with pro-trade inclinations in skill-scarce countries." (Baker 2005: 925)

Baker's implicit argument is that the previously observed positive relationship or no relationship between skills and support for free trade in less developed countries (LDCs) may have resulted from a failure to differentiate between the effect of skills and the effect of income. The empirical analysis that follows will reveal, however, that Baker's argument does not square well with empirical data about how people frame the consequences of free trade policy.

4. Beaulieu et al. (2004) suggest that the empirical anomaly may result from the fact that world trade liberalization has disproportionately affected skillintensive goods, but more empirical research is still needed to support this argument. 


\section{An Alternative Approach: Ignorance, Resources, and Embedded Attitudes}

Free trade policy is rarely the subject of intense political debate. For most people the economic processes that lead to them being hired or dismissed, getting a raise or not getting a raise, are rather opaque and unrelated to trade policy. ${ }^{5}$ Most people, especially in post-industrial societies, are involved in activities that are not directly exposed to foreign competition and that are not organized toward the conquest of foreign markets. For this majority of workers deciding on the best trade policy is an unusual gamble with no entry fee and unknown outcomes (since they are generally ignorant of both the potential gains and losses and their respective probabilities). Furthermore, in the context of a survey, respondents are aware that their answers to the question on trade policy are likely to be inconsequential.

Our model thus starts from totally opposite premises to those used in the literature on attitudes to free trade. Previous research assumes that the population knows both what are the various individual outcomes that will result from liberal and protectionist trade policies for people with their same work skills and the probabilities attached to these outcomes. We argue instead that the majority of people are not well informed and that answers to survey questions on attitudes to free trade in fact correspond to an extreme case of what economists describe as "choice under complete ignorance" (Luce and Raiffa 1957; Cohen and Jaffray 1980). The difference between our topic of investigation and the topics that concern the literature on choice under complete ignorance is that whereas the latter deal with situations where the actor is aware of the potential outcomes of different courses of behavior but has no knowledge of the probabilities attached to the different outcomes, in our case actors generally do not even know what the outcomes are. It is this lack of information that should drive empirical relationships when examining attitudes to free trade among the general population.

When rational people are uninformed about a topic, any bit of information or cue they may obtain from the environment is disproportionately important for the choices they make. Consequently, the form and content of a question that refers to a topic about which people have rarely thought is bound to matter more than under circumstances in which people are more informed. This is highly relevant to our study. Cognitive social scientists have long recognized the power of words in shaping cognition and emotion through "connotation" (Besnier 1990). The use of loaded words when presenting choices has also been subject to a vast literature in the field of survey research (Payne 1951; Foddy 1993). In the context of the explanation of attitudes to

\footnotetext{
5. In a recent book, Robert Fishman (2006) convincingly demonstrates the role that intellectuals can play in enlightening workers about the less immediate factors that impinge on their labor conditions.
} 
free trade, this research becomes relevant because questions on trade policy often use the loaded words "barriers" or "protection". ${ }^{6}$ The framing of tariffs as "barriers" or "protection" is likely to trigger people's demonstrated greater sensitivity to potential losses than to potential gains (e.g. Camerer, Loewenstein, and Rabin 2003), and more so among those groups in the population, the poor, women, and the old, which the literature shows as most risk- and loss-averse (Dohmen et al. 2006; Hartog, Ferrer-iCarbonell, and Jonker 2002).

In line with the experimental literature on risk- and loss-aversion, our analytical model predicts a negative relationship between how vulnerable people are and support for free trade policy. It is a fair assumption that in any society men and people of higher socioeconomic status (e.g. wealthier and more educated individuals, and skilled workers) are more economically secure than are women and people of lower socioeconomic status. Wealthier people have more economic and social capital resources to fall back on if the worse happens--e.g. the loss of a job--than have poorer people, whereas educated and high skilled workers possess non-job specific work skills that can help them navigate the transition from one job to another, if need be (Gabel 1998; Beaulieu et al. 2004). We would thus expect these groups to be less sensitive to the specter of serious economic losses evoked by questions on attitudes to trade policy that oppose free trade to "barriers" or "protection". 7

The main hypothesis in this article will thus be the following:

Hypothesis 1a: "The fewer economic and human capital resources individuals have, the more they will oppose free trade."

Compared to previous approaches to the explanation of attitudes to free trade, our approach is more realistic about the reasoning presiding people's answers to trade policy, more parsimonious, because it ties in one single hypothesis the observed tendency for higher earners, high-skilled workers, men, and young people to be both less risk averse and less opposed to free trade. Furthermore, our approach solves the thorny issue of explaining why, contrary to predictions based on trade theory, skilled workers are more favorable to free trade, regardless of levels of economic development. Our model does not only predict this to happen, whether we measure skills through occupation or levels of education, but also predicts that wealthier people will everywhere be more supportive of free trade than are poorer people. While Baker has also predicted this to happen by extending trade theory from producers to consumers, we will show below that the mechanism he invokes is unlikely to explain the income-attitudes to trade relationship.

6. Interestingly, most widely spoken languages use to describe tariffs--e.g. protectionisme, proteccionismo, Protektionismus, hogo-shugi.

7. Except, perhaps, those who have absolutely nothing to lose, and who, in any case, will not be sufficiently represented in a national representative survey. 
Following the line of argument sketched thus far, and taking stock of developments in economic sociology that stress the embeddedness of economic behavior (e.g. Granovetter 1981; Polanyi 1971 [1957]), we also expect welfare institutions that reduce people's economic vulnerability to diminish their sensitivity to questions about trade policy. As Hays, Ehrlich, and Peinhard (2005) have demonstrated, but only for OECD countries, the potential costs of a free trade policy for selected segments of the population, in the form of unemployment and falling real wages, are experienced differently in societies with strong (e.g. social-democratic) welfare states compared to societies with weak (e.g. liberal) welfare states. This means that the population's sensitivity to these potential costs of free trade may be lower in the former societies than in the latter and that attitudes to free trade will vary accordingly. Hays et al. (2005), however, as well as Adserà and Boix (2002; see also Boix 2002), approach the role of welfare institutions from a perspective that is wedded to the Stolper-Samuelson theorem and to the assumption that citizens--or at least an enlightened group of citizens-are well informed about the consequences of free trade for different segments of society. This is fine, as long as one focuses, as Adserà and Boix do, on the explanation of trade policy, for one can assume that labor unions can estimate with some accuracy the direct and short term costs of different trade policies to their constituency and bargain accordingly for compensation in the form of greater public expenditure. If what we want to do, however, is to posit and interpret an empirical relationship between the strength of the welfare state and citizen support for a free trade policy, it is more realistic to start from the assumption that individuals generally do not reflect or have enough information on the economic consequences of trade policies. Because of this lack of reflection and information, their attitudes to free trade will thus be based not on expected benefits or losses, but rather, on their relative ability to confront potential losses. This ability to confront losses increases with the strength of the welfare state. Therefore, our subsidiary hypothesis $1 \mathrm{~b}$ reads as follows:

Hypothesis 1b: "The more protection a state offers against the negative individual consequences of the market, the lesser the population's perceived vulnerability, and the less "protectionist" the population will be."

The context-embeddedness of economic behavior also leads us to develop predictions about the impact of the economic environment on people's answers to questions on trade policy. One would expect this economic environment to make more or less real in people's minds the sense of economic doom implicit in the framing of barriers to trade as geared toward "protecting" the national economy. External macroeconomic factors, especially those semantically closer to trade policy (i.e. trade balance figures), act as signals that further condition the individuals' choices by shaping their perceptions of how vulnerable they are. Bad times will make them feel more vulnerable and thus more supportive of barriers to trade whereas good times will make them feel less vulnerable and thus less favorable to such barriers.

Our argument differs from traditional approaches to the role of macroeconomic factors in guiding attitudes to free trade among the population. The traditional approach assumes rational, calculating individuals who can link macroeconomic trends 
to trade policy choices. We dispute this assumption and propose instead that what macroeconomic trends mainly do is increase or decrease the citizens' perceptions of vulnerability. Thus, whereas the traditional approach does not provide an explanation for why some macroeconomic indicators matter more in the explanation of attitudes toward free trade, the alternative approach proposed here expects macroeconomic indicators whose relationship to one's degree of vulnerability is easier to read by uninformed citizens or that bear a clearer semantic relationship to trade policy to impact more on attitudes to trade than do other macroeconomic indicators. Hypothesis $2 \mathrm{a}$ and $2 \mathrm{~b}$ thus read as follows:

Hypothesis 2a: "The better the economic climate is, the less vulnerable the population will feel, and the less "protectionist" it will be."

Hypothesis 2b: "The tighter the semantic connection between a macroeconomic indicator and trade policy is, the stronger its effect on people's attitude to free trade."

Although our analytical model is premised on widespread ignorance, we expect the most politically aware segments of the population to at least be aware of the positions on trade policy of interest groups, political parties, governments, and international organizations and to be influenced by them. Endorsements of one or another policy by interest groups and political actors can thus influence attitudes to free trade. ${ }^{8}$ This is indeed what happened in the early 90s US Presidential election when Ross Perot used the NAFTA Treaty as the cornerstone of his campaign. More generally, endorsements of particular trade policies can materialize in institutions such as law and policies, as well as in academic textbooks, that contribute to the development of trade policy traditions in particular countries. Hainmueller and Hiscox (2006) argue that high-skilled workers are more supportive of free-trade than are lessskilled workers, not so much because of the material advantages that they personally experience or expect based on their skills but rather because of their beliefs in the tenets of neoclassical economics, which they acquire through higher-education institutions. We see merit in Hainmueller's and Hiscox's argument, although we believe that if ideas impact on people's attitudes to free trade, it is rather through other more wide-reaching vehicles, like the media and policy traditions. ${ }^{9}$ The post-WWII period, and especially the last thirty years, have been marked by the rise of free trade as the dominant and institutionalized trade policy, especially at the international level of governance. Generally speaking, we would thus expect that ceteris paribus politically informed segments of the population (e.g. the most educated ones) are less sensitive to how specific questions on trade policy are framed and are more favorable

8. On frames and social movements, see Snow et al. 1986; see also Beaulieu et al. 2004; Gabel 1998.

9. Although Hainmueller's and Hiscox's interpretive hypothesis is imaginative and agrees with this article's approach and with the ideational turn in comparative politics and international relations studies, it is not entirely convincing. For one, the status of neoclassical economic theory has varied over time, so that different generations of students have been exposed to different theoretical approaches to economics (e.g. Babb 2001). Also, there is great national diversity in higher-education systems and one should not assume that undergraduate students throughout the world are equally socialized into the virtues of neoclassical economics. Finally, the authors candidly assume that students at universities accept willy-nilly what they are taught rather than adhere to the ideological counter-currents that usually prevail in university environments. 
to free trade than less politically informed segments of the population. In addition, we would expect supporters of moderate left and right political parties to be more supportive of free trade than supporters of far right (nationalists) and far left parties (anticapitalists). Finally, we would expect attitudes to free trade to vary across states, depending on policy traditions. These three related hypothesis read as follows:

Hypothesis 3a: "The more educated citizens are, the more exposed they are to the dominant free trade ideology, and the more they support free trade."

Hypothesis 3b: "Supporters of moderate left and right political parties are more exposed to political endorsements of free trade, and are therefore more supportive of free trade than are supporters of far right and far left political parties."

Hypothesis 3c: "The more established a free-trade policy tradition is, the lesser the uncertainty involved in the choice between free trade policies, the greater the confidence in the advantages of free trade, and the less "protectionist" the population will be."

Table 1 Theoretical Predictions Corresponding to the Cognitive Analytical Model for the Explanation of Attitude to Free Trade

H1a: "The fewer economic and human capital resources individuals have, the more they will oppose free trade."

H1b: "The more protection a state offers against the negative individual consequences of the market, the lesser the population's perceived vulnerability, and the less "protectionist" the population will be."

H2a: "The better the economic climate is, the less vulnerable the population will feel, and the less "protectionist" it will be."

$\mathrm{H} 2 \mathrm{~b}$ : "The tighter the semantic connection between a macroeconomic indicator and trade policy is, the stronger its effect on people's attitude to free trade."

H3a: "The more educated citizens are, the more exposed they are to the dominant free trade ideology, and the more they support free trade."

H3b: "Supporters of moderate left and right political parties are more exposed to political endorsements of free trade, and are therefore more supportive of free trade than are supporters of far right and far left political parties."

H3c: "The more established a free-trade policy tradition is, the lesser the uncertainty involved in the choice between free trade policies, the greater the confidence in the advantages of free trade, and the less "protectionist" the population will be." 


\section{What Do People Know? Knowledge and Frames about Free Trade}

\subsection{Data}

The validity of our alternative analytical argument hinges to a large extent on demonstrating that the population has little or no information about trade policy and that people's perceptions of the pros and cons of alternative trade policies have little impact on their final attitudes and on the explanation of observed contrasts among groups in support for free trade. To examine these questions we use data from a survey conducted in Spain in May 2009. ${ }^{10}$ This national representative survey allows us to measure in three different ways the degree of information the population has about free trade and to inquire about the sources of this information. First, we rely on the percentage of respondents who were able to answer a question about their attitudes towards free trade. The question reads as follows:

"Generally speaking, do you strongly agree, agree, disagree, strongly disagree, or have you not given it enough thought, with the existence of barriers to the import of foreign products? [En general, ¿está Vd. muy de acuerdo, de acuerdo, en desacuerdo, muy en desacuerdo, o no lo ha pensado con que hay barreras a la importación de productos extranjeros?]

The survey question is worded in relatively neutral terms. The words "barrier" and "foreign" are loaded, however, which could bias the distribution of answers toward protectionist attitudes and simultaneously prompt more frequent anti-free-trade responses among the most economically vulnerable and nationalist social groups in the sample than among the rest of the respondents.

The percentage of people who neither support nor oppose trade barriers provides us with a first glimpse at the degree of knowledge that people have about trade policy. In addition to this information, however, the survey questionnaire provides two additional opportunities to measure people's knowledge of trade policy. Firstly, it includes an item that directly inquires about the respondents' perceived knowledge. This question reads as follows:

"Would you say that you know a lot, some, little, or nothing about the consequences of raising or lifting barriers to the import of foreign products?" [¿Diria que sabe mucho, bastante, poco, o nada sobre las consecuencias de imponer o levantar barreras a la importación de productos extranjeros?]

10. This national-representative survey was conducted by ASEP, a well-established research institute involved in the World Values Survey, the International Social Survey Program (ISSP), and the Comparative Study of Electoral Systems (CSES), among other major surveys. 
Secondly, the questionnaire asks respondents in open-ended form to mention up to three consequences that would result from completely lifting barriers to the import of foreign products. The question reads as follows:

"What would you say would happen if there were no barriers to the import of foreign products, or have you not given thought to this question?" [" ¿En su opinión qué pasaría si no hubiera ninguna barrera a la importación de productos extranjeros, o no ha pensado sobre el tema?]

Finally, the questionnaire includes a question about how often people discuss trade policy with those close to them. The question reads as follows:

"In your closest environment, family, friends, and work colleagues, have you ever heard comments about the import of foreign products?" ["¿En el entorno en que se mueve, familia, trabajo, o amigos, iha oído $V d$. alguna vez comentarios relativos a la importación de productos extranjeros?"]

In the analysis below we look at these variables' frequency distributions. In addition to this, and in order to accomplish our second objective, a test of the traditional trade policy models' assumptions concerning the mechanisms mediating socio-demographic characteristics and attitudes to free trade, we estimate a series of Heckman-probit selection models. These models help us control for potential selection bias derived from the fact that variables that explain why people do not answer the question on attitudes to free trade may also be related to the dependent variable in the analysis. The dependent variable in the selection part of the model is whether or not respondents took sides on the issue of the existence of trade barriers. Those who agreed or disagreed with trade barriers are coded " 1 " and those who neither agreed nor disagreed are coded " 0 ". The independent variables in our selection model are the respondents' highest educational degree and a scale of exposure to political information. The latter was constructed by adding the number of sources of information that respondents used during the week preceding the survey. The list of sources of information includes newspapers, radio news shows, magazines, TV news programs, books, in-depth radio reports, Internet or e-mail, and in-depth TV reports. We expect more educated and better informed respondents to be more able to position themselves for or against barriers to free trade than do less educated and less informed ones.

The multivariate part of the model for the explanation of attitudes to trade policy uses the answers to the question related to trade barriers described above as the dependent variable. This variable has been coded as a dummy variable $(0,1)$, with " 1 " meaning that respondents disagree with barriers to the import of foreign goods. The first independent variable in these multivariate statistical models is a measure of the respondents' consumer power. It affords us a first approximation to the analysis of the impact of economic vulnerability on attitudes to free trade and, at the same time, taps on the consumer dimension referred to by Baker in his explanation of attitudes to trade policy. We measure consumer power through a factor scale constructed from two items in the survey: the respondents' highest degree of education, which taps on the respondents' socioeconomic status, and the number of owned consumer products from a list provided in 
the questionnaire. ${ }^{11}$ The list includes the following items: House, car, dishwasher, Video, DVD, telephone, cell phone, computer, mp3, Internet service, and DSL Internet service. The correlation between these two items and the factor is of 0.87 . Other variables in this part of the statistical analysis are the respondent's age and gender, a dummy variable that measures whether respondents are unemployed, another dummy variable that measures whether respondents are manual workers, and a final variable that measures the strength of nationalist feelings. The latter is based on an item taken from the ISSP 2003 survey that reads as follows:

\section{"People should defend their country even when it is in the wrong."}

Respondents were asked to react to the statement on a 4-point Agreement-Disagreement Likert scale.

The full-information factor endowment model is premised on the idea that those who oppose free trade do so because they perceive negative consequences for people with their occupational skills whereas those who favor free trade do so because they perceive positive consequences for people with their occupational skills. In turn, Baker tells us that the wealthy support free trade more than the poor because of the greater benefits they derive from the sinking of prices of imported products. If these logics are at work, we would expect to observe statistical associations between the consequences people perceive in alternative trade policies and their attitudes to these policies. We use the answers to the open-ended question about the expected consequences of the lifting of trade barriers to compute a series of dummy variables that, after inclusion in the statistical models, allow us to empirically test the validity of these expectations. We would expect, for instance, that people who think that free trade leads to "more unemployment" would oppose free trade more than those who do not think this way and, also, that people who think that free trade leads to "lower prices" would support free trade more than those who do not think this way.

\subsection{Results}

Table 2 displays the percentages of respondents who lack any knowledge about free trade as ascertained through the first three questions described above. It shows that $34.1 \%$ admit to know nothing about free trade and $82 \%$ admit to know little or nothing. Also, 33.6\% admit that they know too little to be able to answer the question on attitudes to free trade. The correlation between these two variables is of 0.42 .

11. We tried using "income" instead, but the percentage of respondents who failed to provide information on this variable was equal to $40 \%$ which, coupled with the large percentage of missing data on the dependent variable in the analysis, created a serious loss of cases. The correlation between income and the measure of consumer power is .60 . 
Meanwhile, our indirect measures of knowledge show first that $27.2 \%$ are incapable of mentioning one single consequence of free trade. The correlations between this indicator and the two direct measures of knowledge are lower, 0.14 and 0.22 respectively, which suggests that the consequences of free trade policy that many respondents mention are not grounded on serious reflection. ${ }^{12}$ Table 2 also shows that $61.6 \%$ answer that they have never heard a comment about the import of foreign products from family, friends, and work colleagues.

The percentages in Table 2 clearly demonstrate that knowledge about trade policy is much less pervasive than assumed in the literature on attitudes to free trade. Furthermore, it shows that it is not through their close networks that most individuals develop their views on trade policy. Table 3 displays the percentages of respondents who mention one or another consequence of free trade. ${ }^{13}$ The range of answers reveals a great diversity of views, which at the same time does not exactly mirror neither the elegant premises of trade theory nor the literature's expectations. More variety, lower prices, less variety, better quality, and more unemployment are the main consequences that respondents associate with free trade. We also see that free trade is associated with contradictory economic developments. For instance, $22 \%$ of the respondents think that it leads to lower prices whereas $11 \%$ think that it leads to higher prices.

\begin{tabular}{|l|l|}
\hline Table 2 Extent of Knowledge about Trade Policy (in \%, Spain 2009) & 33.6 \\
\hline Does not know how to answer to question on attitudes to trade barriers & 34.1 \\
\hline Admits to have no knowledge about trade policy & 82.1 \\
\hline Admits to have little or no knowledge about trade policy & 27.2 \\
\hline Cannot mention a single consequence of free trade & 61.6 \\
\hline Has never heard a comment on foreign imports & \\
\hline
\end{tabular}

Source: ASEP (May, 2009); N=1,065.

\section{Table 3 Relative Salience of Frames about Free Trade Policy (Spain 2009)}

\begin{tabular}{|c|c|c|}
\hline & $\%$ Mention & Ranking \\
\hline Higher Prices & 10.9 & 6 \\
\hline Lower Prices & 21.5 & 2 \\
\hline More Variety & 22.9 & 1 \\
\hline Less Variety & 15.0 & 3 \\
\hline Better Quality & 13.3 & 5 \\
\hline Worse Quality & 3.0 & 13 \\
\hline More Unemployment & 14.8 & 4 \\
\hline Less Unemployment & 4.0 & 11 \\
\hline More Economic Growth & 5.6 & 8 \\
\hline Less Economic Growth & 13.3 & 5 \\
\hline More Economic Inequality & 7.2 & 9 \\
\hline Less Economic Inequality & 3.4 & 12 \\
\hline Weaker National Identity & 9.7 & 7 \\
\hline More Modern Country & 4.6 & 10 \\
\hline
\end{tabular}

Source: ASEP (May, 2009); N=1,065.

12. We take the alternative possibility, that people are modest about their real knowledge as unlikely.

13. We have left out answers that could not fit in any of these categories. They represent $6.4 \%$ of the total number of consequences that were mentioned. 
We now move to the models for the explanation of attitudes to trade barriers. The selection part of the model reveals that the effects of education and political information have the predicted sign and are always statistically significant (see Table 4). The lack of significance for the rho coefficient in the different estimated models also reveals that selection processes do not significantly impact on the estimation of the effect of different independent variables on attitudes to free trade. In fact, the results were identical when we fitted multinomial logit models that treated DKs as a possible choice and when we estimated simple logit models with no selection model.

Table 4 shows first of all that respondents with more consumer power are more opposed to trade barriers than other respondents. The relationship is statistically significant in all models except for the last one, which includes all the interaction variables between consumer power and each of the framing variables. The statistical results also show that manual workers are more "protectionist" than the rest of the respondents in the sample. The relationship is statistically significant in all models. Finally, Table 4 shows that the more nationalist respondents are, the more they support the existence of trade barriers. The results are statistically significant in all models too. We will have an opportunity to better examine the effect of these individual-level variables in the statistical analysis below, which uses data for a large number of countries. At this point we are mostly interested in the effects of expectations about the consequences of free trade on people's attitudes to trade barriers, and in the extent to which these frames mediate the relationships between the respondents' socio-demographic characteristics and their attitudes.

Table 4 shows that there are five frames whose effects on people's attitudes to trade barriers are statistically significant, after controlling for the respondents' sociodemographic characteristics and other frames (see column 3). These frames are those concerning more product variety, more economic growth, less economic growth, more unemployment, and worse products. All the statistically significant coefficients have the predicted sign. Interestingly, the conceptualization of free trade as contributing to lower prices, a key element in Baker's consumer model, does not show the predicted effect on attitudes to trade barriers. ${ }^{14}$

14. Additional models not displayed in Table 4 lend support to economic theories that stress the importance of loss aversion in individual decisionmaking (see note at bottom of Table 4). The model with only negative frames fits the data better (-Log $\mathrm{L}=-1044.339$ ) than does the model with only positive frames (-Log $\mathrm{L}=-1052.532)$. The difference is statistically significant at the .05 level. 
Table 4 The Effect of Frames on Attitudes to Trade Barriers (Spain 2009)

\begin{tabular}{|c|c|c|c|c|}
\hline & $\begin{array}{c}\text { Against Protection } \\
\text { (1) }\end{array}$ & $\begin{array}{c}\text { Against Protection } \\
\text { (2) }\end{array}$ & $\begin{array}{c}\text { Against Protection } \\
\text { (3) }\end{array}$ & $\begin{array}{c}\text { Against Protection } \\
\text { (4)a }\end{array}$ \\
\hline Consumer Power & $\begin{array}{c}0.21^{*} \\
(0.08)\end{array}$ & $\begin{array}{c}0.18^{*} \\
(0.08)\end{array}$ & $\begin{array}{c}0.18^{*} \\
(0.09)\end{array}$ & $\begin{array}{c}0.15 \\
(0.11)\end{array}$ \\
\hline Manual Worker & & $\begin{array}{l}-0.27^{*} \\
(0.13)\end{array}$ & $\begin{array}{l}-0.31^{*} \\
(0.14)\end{array}$ & $\begin{array}{l}-0.32 * \\
(0.14)\end{array}$ \\
\hline Unemployed & & $\begin{array}{c}0.02 \\
(0.14)\end{array}$ & $\begin{array}{l}0.05 \\
(0.15)\end{array}$ & $\begin{array}{l}0.07 \\
(0.15)\end{array}$ \\
\hline Gender & & $\begin{array}{c}0.04 \\
(0.10)\end{array}$ & $\begin{array}{l}0.00 \\
(0.11)\end{array}$ & $\begin{array}{l}-0.00 \\
(0.11)\end{array}$ \\
\hline Age & & $\begin{array}{c}9.57 \mathrm{E}-04 \\
(3.46 \mathrm{E}-03)\end{array}$ & $\begin{array}{c}3.16 \mathrm{E}-03 \\
(3.61 \mathrm{E}-03)\end{array}$ & $\begin{array}{l}3.32 \mathrm{E}-03 \\
(3.64 \mathrm{E}-03)\end{array}$ \\
\hline Nationalism & & $\begin{array}{l}-0.11^{*} \\
(0.04)\end{array}$ & $\begin{array}{l}-0.13 * \\
(0.04)\end{array}$ & $\begin{array}{l}-0.12 * \\
(0.04)\end{array}$ \\
\hline High Prices & & & $\begin{array}{l}-0.10 \\
(0.16)\end{array}$ & $\begin{array}{l}-0.09 \\
(0.17)\end{array}$ \\
\hline High Growth & & & $\begin{array}{l}0.46^{*} \\
(0.22)\end{array}$ & $\begin{array}{l}0.49 * \\
(0.23)\end{array}$ \\
\hline Less Unemployment & & & $\begin{array}{l}-0.37 \\
(0.27)\end{array}$ & $\begin{array}{l}-0.41 \\
(0.29)\end{array}$ \\
\hline Variety of Products & & & $\begin{array}{l}0.46^{*} \\
(0.14)\end{array}$ & $\begin{array}{l}0.46^{*} \\
(0.15)\end{array}$ \\
\hline Better Products & & & $\begin{array}{l}-0.08 \\
(0.17)\end{array}$ & $\begin{array}{l}-0.12 \\
(0.18)\end{array}$ \\
\hline More Unemployment & & & $\begin{array}{l}-0.47^{*} \\
(0.15)\end{array}$ & $\begin{array}{l}-0.49 * \\
(0.16)\end{array}$ \\
\hline Lower Prices & & & $\begin{array}{l}0.05 \\
(0.14)\end{array}$ & $\begin{array}{l}0.07 \\
(0.15)\end{array}$ \\
\hline Weak Identity & & & $\begin{array}{c}0.29 \\
(0.18)\end{array}$ & $\begin{array}{l}-0.31 \\
(0.18)\end{array}$ \\
\hline Worse Products & & & $\begin{array}{l}-0.28^{*} \\
(0.14)\end{array}$ & $\begin{array}{l}-0.34 * \\
(0.15)\end{array}$ \\
\hline Less Growth & & & $\begin{array}{l}-0.44 * \\
(0.15)\end{array}$ & $\begin{array}{l}-0.44 * \\
(0.16)\end{array}$ \\
\hline Less Variety & & & $\begin{array}{l}0.25 \\
(0.26)\end{array}$ & $\begin{array}{c}0.29 \\
(0.27)\end{array}$ \\
\hline Modern & & & $\begin{array}{l}-0.08 \\
(0.23)\end{array}$ & $\begin{array}{l}-0.06 \\
(0.21)\end{array}$ \\
\hline More Inequality & & & $\begin{array}{l}-0.15 \\
(0.22)\end{array}$ & $\begin{array}{l}-0.08 \\
(0.23)\end{array}$ \\
\hline Less Inequality & & & $\begin{array}{l}-0.41 \\
(0.32)\end{array}$ & $\begin{array}{l}-0.36 \\
(0.32)\end{array}$ \\
\hline Constant & $\begin{array}{l}-0.23 \\
(0.43)\end{array}$ & $\begin{array}{c}0.02 \\
(0.46)\end{array}$ & $\begin{array}{l}0.22 \\
(0.45)\end{array}$ & $\begin{array}{l}0.25 \\
(0.44)\end{array}$ \\
\hline \multicolumn{5}{|l|}{ Selection Model } \\
\hline Education & $\begin{array}{l}0.06 * \\
(0.03)\end{array}$ & $\begin{array}{l}0.06 * \\
(0.03)\end{array}$ & $\begin{array}{l}0.06 * \\
(0.03)\end{array}$ & $\begin{array}{l}0.06 * \\
(0.03)\end{array}$ \\
\hline Political Information & $\begin{array}{l}0.08^{*} \\
(0.02)\end{array}$ & $\begin{array}{l}0.08^{*} \\
(0.02)\end{array}$ & $\begin{array}{l}0.08^{*} \\
(0.02)\end{array}$ & $\begin{array}{l}0.08 * \\
(0.02)\end{array}$ \\
\hline Constant & $\begin{array}{l}-0.07 \\
(0.11)\end{array}$ & $\begin{array}{l}-0.06 \\
(0.11)\end{array}$ & $\begin{array}{l}-0.06 \\
(0.11)\end{array}$ & $\begin{array}{l}-0.06 \\
(0.11)\end{array}$ \\
\hline Prob rho & 0.95 & 0.93 & 0.90 & 0.80 \\
\hline$-\log L$ & -1074.54 & -1068.34 & -1033.41 & -1030.3 \\
\hline $\mathrm{N}$ & 651 & 651 & 651 & 651 \\
\hline
\end{tabular}

Source: ASEP (May, 2009); N=1,065.

Note: Model 4a: Model with Interactions between Consumer Power and frames.

--Log L for Model with only positive frames: -1052.532

--Log L for Model with only negative frames: -1044.339

Heckman-probit selection models; ${ }^{*}=$ significant at .05 level, two-tailed. 
The most important findings in column 3, however, are that people's frames about free trade only marginally contribute to explain attitudes to trade barriers and, in addition, that the coefficients for the measures of consumer power and manual work remain unaltered when we include the frame variables in the models. This means that wealthier consumers' greater opposition to trade barriers is not due to their thinking that free trade contributes to lower prices, more variety, and better products and that the manual workers' greater support for trade barriers is not explained by their expecting that free trade will lead to higher unemployment.

One could still argue that the explanation for the statistical findings is that social groups differ in how sensitive they are to particular representations of the consequences of trade policy. It is indeed plausible that individuals with low consumer power, while aware of the effect of free trade on prices, are insensitive to this, simply because their low acquisitive power does not allow them to take advantage of lower prices for imports. To test for this possibility we fitted a fourth model, which included the various frames and interaction terms for the relationship between consumer power and support for trade restrictions. Model 4 displays this test's results. Since none of the interaction coefficients are statistically significant we omit them in the table. ${ }^{15}$ The reader can nonetheless notice that the change in the -Log $\mathrm{L}$ value between this and model 3 is actually trivial. To take possible multicollinearity into account we also tested models in which we included interaction terms one at a time. None of the obtained coefficients was statistically significant. Thus the main conclusion to be drawn from this statistical analysis is that we cannot explain attitudes to trade policy by invoking people's expectations about the impact of free trade policy on those with similar work skills or purchasing power to theirs. Although we cannot establish these results' external validity we have no reason to think that they would have been very different in other countries. At the very least they support our analytical approach to the explanation of attitudes to free trade, which rests on the assumption of "choice under complete ignorance of outcomes and their probabilities"16

15. These results are available from the authors upon request.

16. We replicated all these models using a multinomial approach, with DKs as just another category, and as simple logit models, only with those who agreed or disagreed. The results were always the same, as one would expect given that rho, which measures the impact of sample selection on the final results, is not statistically significant. 


\section{Ignorance, Resources, and Embeddedness in the Explanation of Attitudes to Free Trade}

\subsection{Data}

The second survey dataset we use in this article is the ISSP 2003 survey, conducted in 41 developed and developing countries. Our analysis focuses on the 32 countries for which we were able to obtain measures for all individual and aggregate-level variables. ${ }^{17}$ The 2003 ISSP replicates the measure used in the 1995 ISSP survey which all comparative studies, except for Baker's, have used in order to test their analytical and theoretical models. ${ }^{18}$ It is an ordinal measure based on answers to the following question:

"How much do you agree or disagree with the following statements?...

\section{Statement:}

'The country should limit the import of foreign products in order to protect its national economy'."19

The variable is coded so that high values express protectionist attitudes. It frames the choice over trade policy as a choice between the status quo and a change involving a potential gain of uncertain magnitude--" protection"--and benefitting the country's economy rather than particular individuals. As discussed above, the word "protection" is loaded and evokes the specter of a serious threat that could potentially lead to a major loss. Barriers to trade are thus framed as an uncertain gain to prevent a potentially major loss. ${ }^{20}$ We can use information on how the 2003 ISSP question on trade policy was framed to develop predictions about which groups are likely to be more supportive of protectionism. In particular, we expect individuals who feel in need of economic protection to be more sensitive to the information provided by the statement than are those who feel more secure economically.

\footnotetext{
17. The countries are Australia, Austria, Canada, Czech Republic, Chile, Denmark, Finland, France, Germany, Hungary, Ireland, Israel, Japan, Korea, Latvia, New Zealand, Norway, Philippines, Poland, Portugal, Russia, Slovakia, Slovenia, South Africa, Spain, Sweden, Switzerland, Taiwan, United Kingdom, United States, Uruguay, Venezuela.

18. Beaulieu et al. 2004; Mayda and Rodrik 2005; Hays, Ehrlich, and Peinhardt 2005. Baker's recent article (2005), to which we refer in the text, is based on the World Values Survey's formulation. This question reads as follows: "Do you think it is better if (1) goods made in other countries can be imported and sold here if people want to buy them or that (0) there should be stricter limits on selling foreign goods here to protect the jobs of people in this country." Contrary to ours, this question is framed as a choice between two possible directions of trade policy, but one would be hard-pressed to claim that it offers neutral choices. It informs respondents about the relationship between free trade and consumption and about the relationship between trade barriers and job "protection". Not informs respondents about the relationship between free trade and consumption and about the relationship between trade barriers and job protection". No these empirical relationships would be as clear as they are if those frames were removed from the question.

19. The answer categories are "strongly disagree", "disagree", "neither agree nor disagree", "agree", and "strongly agree".

20. We see evidence of the impact of how the question is framed when we compare the frequency distribution for this variable with those for differently worded questions. For example, we see that whereas in the 2003 ISSP survey $80 \%$ of the Spanish respondents who took sides on the issue of trade protection (i.e. excluding DKs) agreed with protection, in the May 2009 survey discussed in the previous section only 59\% did so. Since developments such as the enlargement of the European Union to Central and Eastern Europe in 2004 and the current financial and economic crisis actually lead to the opposite expectation, it is conceivable that the difference in wording of the two questions has had significant impact on the observed outcomes. Even more striking is the fact that in another survey also conducted in Spain by ASEP in February 2009, 79\% of the respondents agreed with free trade when the question was worded as follows: "Imports should be made cheaper to stimulate the Spanish economy."
} 
We test Hypothesis 1a ("The fewer economic and human capital resources individuals have, the more they will oppose free trade.") with a variable based on the respondents' selfreported earnings. This information has been used to create a variable that classifies respondents into one of the ten deciles for the within-country distribution of earnings. The second variable that we include in our test of the impact of resources on attitudes to trade is a dichotomous variable that measures the gender of the respondent. This variable is coded 1 for women.

In addition, we include two sets of variables that measure the job-specific character of the respondents' work skills. The first set of variables measures the respondents' highest educational degree. We distinguish between respondents with less than a high school degree (excluded variable), respondents who finished their secondary education, and respondents with university education. The second set of variables measures the respondents' main occupation. We are particularly interested in the contrast between workers with no skills or with skills that are tied to specific jobs, partly because of them being acquired on-the-job, and workers with more transferable skills. Respondents were classified according to the standardized international classification of occupations ISCO88. Those in elementary occupations, plant and machine operators and assemblers, and craft and related trades workers have been classified into one single category (Reference category). We then distinguish between 1) respondents in clerical occupations, 2) Professionals, and 3) Technicians, Managers, Senior Officials, and Legislators.

To test Hypothesis $1 \mathrm{~b}$ ("The more protection a state offers against the negative individual consequences of the market, the lesser the population's perceived vulnerability, and the less "protectionist" the population will be."), we include in the models a measure of the strength of the welfare state. We use a measure of the government's expenditures in areas where they are most likely to impact on the population's degree of economic vulnerability. The IMF's Government Financial Statistics publication provides information on two such categories of expenditure: "Health" and "Social Security and Welfare". With this information, we calculate the expenditure per unit of GDP for each of the countries in the sample.

Hypothesis $2 \mathrm{a}$ and $2 \mathrm{~b}$ state that "The better the economic climate is, the less vulnerable the population will feel, and the less "protectionist" it will be" and also that "the tighter the semantic connection between a macroeconomic indicator and trade policy is, the stronger its effect on people's attitude to free trade."

To test these hypotheses we follow Mansfield and Busch in using a measure of unemployment at the year of the survey to evaluate current economic conditions (Mansfield and Busch 1995). Our statistical model also includes a measure of net trade flows at the time of the survey. This measure is the ratio of the trade balance (Exports - Imports) to the GDP in the year of the survey.

Hypotheses 3a to 3c focus on the embeddedness of people's attitudes to free trade in national and international contexts where interest groups, political parties, governments, and institutions endorse particular trade policies (ㅁa: "The more educated citizens 
are, the more exposed they are to the dominant free trade ideology, and the more they support free trade." 3b: "Supporters of moderate left and right political parties are more exposed to political endorsements of free trade, and are therefore more supportive of free trade than are supporters of far right and far left political parties."; 3c: "The more established a free-trade policy tradition is, the lesser the uncertainty involved in the choice between free trade policies, the greater the confidence in the advantages of free trade, and the less "protectionist" the population will be."). We measure the respondents' education as described above. Also, we measure support for far right and far left political parties through a dummy variable (1=support for the far right or the far left). Finally, to measure the extent to which respondents live in countries with a strong free trade tradition, we use two indicators. First, we include an indicator of the degree of trade openness. This indicator adds the values of exports and imports and divides the sum by the value of the country's GDP. The value of the indicator measures both the relevance of trade for a country's economy and the extent of trade barriers in the country. We expect that, holding the values of other variables in the model constant, the higher the value of this variable the more respondents support free trade. In addition to this, we include a variable that measures the number of years of membership in GATT/WTO. ${ }^{21}$ Some authors claim that popular support for the EU increases with the number of years of membership in the EU because people get more used to the idea of pooling sovereignty with other nations. ${ }^{22}$ Similarly, we predict that the longer a country has been part of organizations that seek to abolish tariffs, GATT/WTO, the longer the population has been exposed to messages in the public sphere that stress the benefits of free trade or that take free trade for granted, the more this country's population will support free trade. ${ }^{23}$

Finally, our statistical analysis includes other control variables that we assume can be related to attitudes to free trade. First, we follow previous empirical findings and include two indicators of the respondents' nationalist feelings (Rankin 2002; Mazer 1998). The justification for this inclusion is that nationalist parties have generally supported protectionist trade policy. Furthermore, the ISSP question is framed in such a way as to tap on these nationalist feelings (i.e. by including the words "protecting the national economy"). The two items are part of a battery of statements and read as follows:

"How much do you agree or disagree with the following statements:...

Statement:

'People should support their country even if it is in the wrong. ${ }^{24}$

\footnotetext{
21. Here we take our cue from the literature on attitudes to European integration, which has traditionally measured socialization processes through an indicator of the number of years that a country has been a member of the European Union (Eichenberg and Dalton 1993)

23. The measure is not perfect, for political factors enter into the decision to admit new members and because once they become members not all countries show the same level of commitment to the removal of barriers to trade, but it reflects at least a minimum commitment to liberalize trade. In fact, comparison of this simple indicator with a measure of the ratio of the value of import duties to the total value of imports, a proxy for the level of openness of national economies in 1980 in a subset of 20 countries for which the measure was available, shows a very strong correlation between the two.

24. The response categories are: agree strongly, agree, neither agree nor disagree, disagree, strongly disagree, can't choose.
} 
We also include a dummy variable that measures whether the respondent is unemployed or not. There is some empirical evidence that unemployed individuals are more risk-averse and therefore we would expect them to be more opposed to free trade policies. We also include this variable to clarify the relationship between education and attitudes to free trade. Hainmueller and Hiscox claim, for instance, that the existence of an interaction effect of education and employment status on attitudes to free trade constitutes supportive evidence for traditional explanations of the effect of education that focus on the relative abundance of workers with different skills, whereas the absence of an interaction supports by default their explanation, which stresses the role of relative exposure of groups with different levels of education to the ideology of free trade (2006).

The analysis also includes a dummy variable that differentiates members of trade unions from those who are non-members. We expect trade union members to have access to more and qualitatively specific information on trade policy and, therefore, to differ in their attitudes from other segments of the population. Furthermore, the factor endowment model expects trade unions to be more favorable to free trade in LDCs than in MDCs, and, consequently, we would also expect workers affiliated to them in these countries to be more favorable to free trade than are workers affiliated to trade unions in MDCs.

Finally, our models include age and a term for the square of age as control variables to take into account recurrent empirical findings that show older people to be more risk averse. Also, the "age" variable taps on the influence of ideas on people's attitudes to free trade (see below), for older people grew up during a period in which neoclassical economics was far from being the hegemonic economic theory in large areas of the world (Babb 2001).

To test the hypotheses discussed above we use a multi-level approach that allows us to decompose the variance in the dependent variable into its within- and betweencountry components. We are thus able to determine how good the micro and the macro dimensions of our model are in explaining attitudes to trade among the population.

\subsection{Results}

Table 5 presents the results of several nested models. Model 1 includes the additive effects of the individual-level variables, except for income, Model 2 adds the income variable, Model 3 adds the interaction terms for level of education and employment status, Model 4 includes the aggregate-level variables, and, finally, Model 5 includes interaction terms for level of education with GDP per capita and for occupation with GDP per capita. 
Table 5 Nested Models for the Explanation of Attitudes to Free Trade

ForFree Trade For Free Trade For Free Trade For Free Trade For Free Trade

\begin{tabular}{|c|c|c|c|c|c|}
\hline & (1) & $(2)$ & (3) & $(4)$ & $(5)$ \\
\hline \multirow{2}{*}{ Age } & $-5.35 \mathrm{E}-03 *$ & $-7.21 \mathrm{E}-03 *$ & $-7.13 \mathrm{E}-03 *$ & $-7.12 \mathrm{E}-03 *$ & -7.50E-03* \\
\hline & (2.16E-03) & $(2.15 E-03)$ & (2.16E-03) & (2.15E-03) & (2.15E-03) \\
\hline \multirow{2}{*}{ Age squared) } & 1.94E-06 & $2.66 \mathrm{E}-05$ & 2.51E-05 & 2.47E-05 & 2.92E-05 \\
\hline & $(2.24 \mathrm{E}-05)$ & (2.25E-05) & (2.25E-05) & $(2.25 \mathrm{E}-05)$ & (2.24E-05) \\
\hline \multirow{2}{*}{ Gender } & $-0.18 *$ & $-0.17 *$ & $-0.17 *$ & $-0.17 *$ & $-0.17 *$ \\
\hline & $(0.02)$ & $(0.01)$ & $(0.01)$ & $(0.01)$ & $(0.01)$ \\
\hline \multirow{2}{*}{ Secondary education } & $0.14 *$ & $0.10 *$ & $0.08 *$ & $0.08 *$ & -0.02 \\
\hline & $(0.02)$ & $(0.02)$ & $(0.02)$ & $(0.02)$ & $(0.03)$ \\
\hline \multirow{2}{*}{ Higher education } & $0.41 *$ & $0.35 *$ & $0.32 *$ & $0.31 *$ & $0.16 *$ \\
\hline & $(0.02)$ & $(0.02)$ & $(0.03)$ & $(0.03)$ & $(0.05)$ \\
\hline \multirow{2}{*}{ Employed } & $-0.04 *$ & $-0.07 *$ & $-0.10 *$ & $-0.10 *$ & $-0.09 *$ \\
\hline & $(0.02)$ & $(0.02)$ & $(0.02)$ & $(0.02)$ & $(0.02)$ \\
\hline \multirow{2}{*}{ Union member } & $-0.04 *$ & $-0.04 *$ & $-0.05 *$ & $-0.05 *$ & $-0.06 *$ \\
\hline & $(0.02)$ & $(0.02)$ & $(0.02)$ & $(0.02)$ & $(0.02)$ \\
\hline \multirow{2}{*}{ Nationalism } & $-0.11 *$ & $-0.11 *$ & $-0.11 *$ & $-0.11 *$ & $-0.11 *$ \\
\hline & $(0.01)$ & $(0.01)$ & $(0.01)$ & (0.01) & (0.01) \\
\hline \multirow{2}{*}{ Patriotism } & $-0.13 *$ & $-0.13 *$ & $-0.13 *$ & $-0.13 *$ & $-0.13 *$ \\
\hline & $(0.01)$ & $(0.01)$ & $(0.01)$ & $(0.01)$ & $(0.01)$ \\
\hline \multirow{2}{*}{ Extreme Politics } & $-0.08 *$ & $-0.07 *$ & $-0.07 *$ & $-0.07 *$ & $-0.08 *$ \\
\hline & $(0.03)$ & $(0.03)$ & $(0.03)$ & $(0.03)$ & $(0.03)$ \\
\hline \multirow{2}{*}{ Professional } & $0.18 *$ & $0.15 *$ & $0.15 *$ & $0.15 *$ & 0.05 \\
\hline & $(0.02)$ & $(0.02)$ & $(0.02)$ & $(0.02)$ & $(0.04)$ \\
\hline \multirow{2}{*}{$\begin{array}{l}\text { High Official, Technical, Managers } \\
\text { and Legislators }\end{array}$} & $0.20 *$ & $0.17 *$ & $0.17^{*}$ & $0.17 *$ & $0.13^{*}$ \\
\hline & $(0.02)$ & $(0.02)$ & $(0.02)$ & $(0.02)$ & $(0.03)$ \\
\hline \multirow{2}{*}{ Clerical } & 0.03 & 0.03 & 0.02 & 0.02 & 3.89E-04 \\
\hline & $(0.02)$ & $(0.02)$ & $(0.02)$ & $(0.02)$ & $(0.03)$ \\
\hline \multirow{2}{*}{ Income } & & $0.03 *$ & $0.03 *$ & $0.03 *$ & $0.03 *$ \\
\hline & & $(2.46 \mathrm{E}-03)$ & $(0.00)$ & $(0.00)$ & $(0.00)$ \\
\hline \multirow{2}{*}{ Secondary education*employed } & & & 0.04 & 0.04 & 0.03 \\
\hline & & & $(0.03)$ & $(0.03)$ & $(0.03)$ \\
\hline \multirow{2}{*}{ Higher education *employed } & & & 0.06 & 0.06 & 0.04 \\
\hline & & & $(0.04)$ & $(0.04)$ & $(0.04)$ \\
\hline Welfare Expenditures/GDP & & & & $0.02 *$ & $0.02 *$ \\
\hline 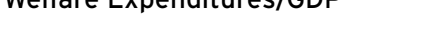 & & & & $(0.01)$ & $(0.01)$ \\
\hline Years in GATT & & & & $-1.86 E-03$ & $-2.07 E-03$ \\
\hline YedIS II GAI I & & & & $(2.95 E-03)$ & (2.92E-03) \\
\hline GDP per capita & & & & 3.97E-06 & $-2.00 E-06$ \\
\hline Gut per capila & & & & (4.78E-06) & (4.77E-06) \\
\hline Unemployment Rates \% & & & & -0.01 & -0.01 \\
\hline 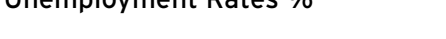 & & & & $(0.01)$ & (0.01) \\
\hline Trade Balance & & & & $0.01 *$ & $0.01 *$ \\
\hline & & & & $(0.00)$ & $(0.00)$ \\
\hline Trade Openness & & & & $-6.48 E-04$ & $-6.30 \mathrm{E}-04$ \\
\hline & & & & (1.59E-03) & (1.57E-03) \\
\hline Secondary ed. * GDP/cap & & & & & $6.21 \mathrm{E}-06 *$ \\
\hline & & & & & (1.05E-06) \\
\hline Higher ed. * GDP/cap & & & & & 8.55E-06* \\
\hline & & & & & (1.50E-06) \\
\hline Professional * GDP/cap & & & & & 4.98E-06* \\
\hline & & & & & (1.64E-06) \\
\hline Higher Official * GDP/cap & & & & & 2.17E-06 \\
\hline & & & & & (1.23E-06) \\
\hline Clerk/Technical * GDP/cap & & & & & 1.81E-06 \\
\hline & & & & & $(1.17 \mathrm{E}-06)$ \\
\hline Constant & $3.59 *$ & $3.52 *$ & $3.53^{*}$ & $3.35^{*}$ & $3.44^{*}$ \\
\hline & $(0.08)$ & $(0.08)$ & $(0.08)$ & (0.19) & $(0.19)$ \\
\hline Group-level variance & 0.09 & 0.09 & 0.09 & 0.04 & 0.04 \\
\hline Individual-level variance & 1.16 & 1.15 & 1.15 & 1.15 & 1.15 \\
\hline $\mathrm{N}$ & 31849 & 31849 & 31849 & 31849 & 31849 \\
\hline
\end{tabular}

Source: ISSP 2003.

Note: $*$ significant at .05 level, two-tailed.

Empty model: group-level variance: 0.11 ; individual-level variance: 1.26 . 


\section{a) Resources, Adaptable Skills, and Support for Free Trade}

We focus first on the effects of income, level of education and occupation (H1a, $\mathrm{H} 1 \mathrm{~b})$, since these effects play a key role in the adjudication between traditional models and our alternative approach. The effect of income on support for free trade is positive and statistically significant across models. Since we know from the statistical results in the previous section that people often do not know what the specific effects of alternative trade policies are and that the effect of income is not mediated by the expectation of lower import prices among those with top incomes, we interpret these results as an indication that the less economically vulnerable individuals are, the more they support free trade..$^{25}$ The observation that opposition to free trade is more prevalent among women than among men is also consistent with the expectation that opposition to free trade is greater among the most economically vulnerable, and therefore, more risk-averse, members of society.

When we shift our attention to the aggregate test of the economic vulnerability hypothesis, we observe that the value of welfare expenditures has the predicted positive effect on support for free trade (see models 4 and 5). Since we have ruled out that the majority of the population bases its trade policy views on information about their potential impact, we can interpret these results as a reflection of less risk-aversion among the populations of strong welfare states.

The effect of education is also in the predicted direction. Respondents with a high school degree and those who have attended university display more support for free trade than do the rest of the respondents. Furthermore, respondents who have attended university support free trade more than those who only completed high school. The association between education and support for free trade holds for those who have attended university, even after controlling for aggregate-level variables and after the introduction of an interaction term for the combined effects of education and GDP/capita (Models 4 and 5). The results for respondents who attended university, the nonlinearity of the effect of education, and the lack of an interaction between education and employment status (Model 3) replicate Hainmueller's and Hiscox's findings with the 1995 ISSP data. ${ }^{26}$

The statistical results are compatible, however, with our expectation that more educated people, because of their less job-specific skills, feel less vulnerable economically. Meanwhile, the education results contradict the full-information, factor endowment model. Indeed, they show that in less developed countries more educated individuals are more favorable to free trade than less educated ones. Only the positive interaction for the combined effect of higher education and GDP/capita supports the traditional approach.

25. In fact, in models not shown here, we observed that, holding the values of the rest of the variables constant, household size (which in contemporary societies increases the economic burden on income earners) is also negatively related to support of free trade (see Caldwell 1976)

26. We conducted a statistical test of the nonlinearity hypothesis and verified that the effect of education is indeed nonlinear. 
The effect of occupation is also generally consistent with our analytical and theoretical model's predictions. The less job-specific the respondents' work skills are, the more they support free trade. Clerks and other service workers are the only occupational group whose attitudes to free trade do not differ from those of manual and other workers with predominantly job-specific skills.

Contrary to the expectations of the full-information, factor endowment model, in less developed countries support for free trade is not higher among manual workers than among other occupational groups. Indeed, Model 5 shows that in LDCs professionals do not differ in their attitudes from workers with job-specific skills, but technicians, managers, high officials, and legislators do and their attitudes are more supportive of free trade than those of workers with job-specific skills. Only the finding that there is an interaction effect for the combined effect of professional occupational status and GDP/capita is consistent with traditional models. The coefficient for this interaction term is positive, which means that the greater the economic development in the country where respondents live, the more respondents in the professional category support free trade relative to respondents with more job-specific skills.

We finish our analysis of the effects of income, education, and occupation by examining the impact of income on the coefficients for the effects of education and occupation on attitudes to free trade. When we compare models 1 and 2 we see that income partly explains these effects. The coefficients for the education and occupation variables, except for the occupational category "Clerical", drop between $15 \%$ and $20 \%$. In a model not displayed here, we see in fact that in the least developed countries the drop in the coefficient for respondents with university education is even greater. Since income has generally not been included in previous tests of the full-information, factor endowment approach, and when it has been included, under the doubtful assumption that the effect of income measures richer people's greater sensitivity to sinking prices for imports (Baker 2006), these results are theoretically relevant. They suggest that previous findings were in fact capturing the effect that economic vulnerability has on people's attitudes to free trade and overestimating the effects of other mediating mechanisms.

\section{b) Economic Signals and Support for Free Trade}

We now explore the effect of the economic context on people's attitudes to free trade. Macroeconomic variables provide respondents with information about current economic conditions, which we expect to have an impact on their perceptions of economic vulnerability. Models 4 and 5 show the effects of unemployment rates and of the trade balance. The effects of unemployment rates are not statistically significant whereas those of the trade balance are. Although we expected a statistically significant effect of unemployment rates on attitudes to free trade, mediated by an enhanced sense of riskaversion among the population, the statistical results still square with our model of decision under complete ignorance. Indeed, since economic signs need to be interpreted, it seems obvious that, other factors held constant, the closer the semantic link between specific macroeconomic indicators and trade policy is, the more likely it is that people will 
take them into account when developing their views on trade policy. A country's trade balance, although not as widely reported in the news as trends in inflation or unemployment, tells people something about a country's ability to compete in foreign markets. Big trade deficits, especially when they accumulate over the years, tend to trigger public debate and often generate demands for protectionist measures. It is thus likely that the population in countries suffering large trade deficits picks up something from these debates. This makes people insecure and, thus, leads to the development of attitudes to free trade that are more protectionist than in countries with more balanced trade flows.

\section{c) Endorsement for Free Trade, Free Trade Traditions, and Support for Free Trade}

We now move to examine the impact of interest groups, political institutions, governments, and national and international institutions on attitudes to free trade (Hypotheses 3a, 3b, 3c). Models 1 thru 5 show that political alignment with the far right or the far left and nationalism has stable effects on opposition to a free trade policy. We interpret this as meaning that individuals take their cues of trade policy from the political organizations with which they identify. Additional models not reported here differentiate between supporters of far right and far left political organizations. The effect of support of far left political organizations has the predicted sign but is not statistically significant. We suspect that this reflects that the diffusion of far left anti-globalization ideology around the world is less pervasive than that of far right nationalist ideology and that the far left is less consistently opposed to globalization processes than is the latter.

Our analysis also explores the impact that the ideology of free trade, institutionalized at the level of international organizations and treaties, in academia, and in governmental policy may have on attitudes to trade. Hainmueller and Hiscox (2006) suggest that the variable education measures just that, and in order to make the argument more persuasive they predict that the effect of education is non-linear and that there is a significant interaction for the combined effect of education and GDP/capita on attitudes to free trade. The statistical results in Models 1 to 5 confirm Hainmueller's and Hiscox's predictions. It is unclear, however, what part of the education effect is due to the fact that more educated individuals are also more adaptable to changes in the labor market and in job requirements, and are therefore less risk-averse, and what part is due to exposure to free trade ideology. The statistical results in models 4 and 5, which show that neither the number of years in GATT/WTO nor the country's degree of openness to trade impact on average individual support for free trade, is somewhat inconsistent with the role that Hainmueller and Hiscox attribute to the population's exposure to free trade ideology. ${ }^{27}$

27. We tested for the existence of an interaction with level of education, to account for the fact that more educated respondents are more attuned to what transpires in the public sphere. The estimated coefficient was not statistically significant. Finally, we tested an alternative prediction derived from the theory, which is that the effect of education on attitudes to free trade will become smaller over time, as exposure to neoliberal ideas on trade becomes prevalent and diffuses from the more educated to the less educated segments of society, and from educated segments in countries with a long free trade policy tradition to educated segments in traditionally more protectionist countries. For this, we compared the coefficients for education in the countries that participated in both the 1995 and 2003 ISSP survey on national identity. The results of this analysis were virtually identical in both years. In fact, what one sees is a slightly greater variance across levels of education in 2003 than in 1995 . Therefore, it remains unclear what is the relative role of ideas compared to job adaptability in explaining the observed relationships between education and attitudes to free trade. We also controlled for Katzenstein's expectation of a negative relationship between a country's size and support for free trade but found no statistically significant relationship (see Katzenstein 1985). 
Finally, models 1 to 5 show that members of trade unions are consistently more opposed to free trade than are other groups in the population. The effect holds after controlling for occupation, education, income, and employment status. In other models not reported here, we did not find significant statistical interaction for the combined effects of union membership and these variables as well as the combined effects of union membership and welfare expenditures and of union membership and GDP / capita. This last result questions again the validity of the factor endowment approach.

d) Individual and Aggregate-level Variables in the Explanation of Attitudes to Free Trade

We now comment on the explanatory power of the various models presented in Table 5: The multi-level approach that we use in this paper allows us to decompose the overall variance in its country and individual components. We see that more than $90 \%$ of the variance in attitudes to free trade corresponds to the individual component. Furthermore, in line with previous statistical analysis, the results presented in Table 5 show that our models explain almost two thirds of the country-level variance and only about $8 \%$ of the individual-level variance. The large percentage of the country variance that our models explain needs to be evaluated with caution. Indeed, we are using variables, like GDP / Capita and type of welfare state, that capture multiple economic and institutional processes and that have demonstrated their explanatory power in a large number of studies. The relatively small number of countries in the sample sets limits, however, on the number of variables that one can use in the statistical models to control for potential confounding effects that compromise the interpretability of the results. More precise measures of the concepts that the theories reviewed in the text invoke could contribute to better evaluate their explanatory power. The small percentage of the individual variance explained by the model presents another sort of problem, misspecification, which means that the obtained coefficients may not accurately reflect the causal impact of the independent variables on attitudes to free trade. We would argue, however, that the results are just what we would expect, given that citizens know close to nothing about trade policy.

\section{Discussion and Conclusion}

The statistical analysis above answers some questions and raises new ones. Overall, however, it demonstrates the usefulness of applying the insights of developments in the cognitive sciences, behavioral economics, and economic sociology to the explanation of attitudes to trade policy. In particular, it clarifies the roles of information, resources, and context in this explanation. The statistical results presented above demonstrate that traditional explanations of attitudes to free trade are inadequate. Information about trade policy is not as widespread as assumed and it does not explain socio-demographic contrasts in the population. One may speculate that many people simply flip a coin when asked 
about their views on free trade. This would explain why most statistical models explain such a small percentage of individual variance in attitudes to free trade.

Our alternative theoretical perspective proposes that an internalized, habitus-like, economic rationality, vehicled through different levels of risk-aversion in the population, underlies attitudes to free trade. One-sided questions on trade policy that use loaded words such as "barriers", "protection", and "foreign" trigger risk-aversion among the most economically vulnerable segments in society, that is, those with few economic resources or with only job-specific skills. Large trade deficits generate alarm about the impact that they may have on the economy, thus increasing aversion to free trade among the population. Welfare institutions diminish the risks of a free trade policy going stray and leading to rising unemployment among some sectors of the labor force. Economic rationality, however, is not the only explanation behind the trade policy choices of this largely uninformed population. Ideology and political affiliation also matter. Thus, traditional opposition to free trade policy by ultraconservative political organizations and, more recently and less extensively, by anti-globalization organizations, provides orientation on trade policy to people who sympathize with or oppose these organizations.

Spelled-out as in the previous paragraph, the story reads simple. Yet, we can be more confident about explanatory mechanisms that do not work than about those that we have tentatively invoked in this article. Neither the Spanish data nor the ISSP data are conclusive with respect to the question of what the calculus involved in people's decisions is, if any. The economic calculus we invoke, founded on economic vulnerability and tied to a "habitus" of risk-aversion, is difficult to measure, simply because actors themselves are likely to be largely unaware of how it impacts their decisions. We also know little about the causal mechanisms that relate nationalist or extreme political positions to opposition to a free trade policy. Does this observed relationship also involve economic calculus on the part of those opposing free trade? Are we in the presence of unreflective reactions to the nationalists' or extremists' political referents? Or does opposition to free trade have something to do with a sui generis form of status defense? More research is needed, that would hopefully provide satisfactory answers to these remaining puzzles.

Some of the findings in this article have important implications for the prospects of globalization. For instance, we show that welfare institutions matter and contribute to increase support for free trade among the population. In this sense the gradual dismantling of the Social Rights Regime does not bode well for globalization. An example of what can happen is the 2004 enlargement of the European Union from 15 to 25 members. Most surveys at the time of enlargement showed that the population was set against it, with support as low as 31\% in countries like France. For good political, moral and, probably, economic reasons, the European Union proceeded with the enlargement and no referendum was held on the issue. Yet, when the French were consulted about the Treaty of Reform of the European Union, the so-called "European Constitution", the fears inspired by the lifting of barriers to the movement of goods, services, capital, and persons, skilfully mobilized by nationalist groups, largely turned this vote into a vote on enlargement and the population's answer was "no, thanks" (Berezin 2009). 
The significance of welfare institutions for the explanation of attitudes to free trade among the population also suggests that other institutions may also matter. The literature has so far assumed, for instance, that the main beneficiaries and losers of the dismantling of trade barriers are those that trade theory predicts. An institutional approach suggests, however, that political and legal institutions, economic policy (e.g. fiscal policy), and corruption levels can considerable distort these distributive processes either by diminishing a country's economic performance or by turning winners into losers and vice versa. This in turn will affect average levels of support for free trade in different countries. One lesson to be drawn from this article's findings is the need to focus future research on attitudes to trade policy on this broader range of institutions and institutional practices.

\section{References}

Adserà, Alicia and Carles Boix. 2002. Trade, Democracy, and the Size of the Public Sector: The Political Underpinnings of Openness. International Organization, 56: 229-262.

Balistreri, Edward J. 1997. The Performance of the Heckscher-Ohlin-Vanek Model in Predicting Endogenous Policy Forces at the Individual Level. Canadian Journal of ECOnomics, 30: 1-17.

Babb, Sarah. 2001. Managing Mexico: Economists from Nationalism to Neoliberalism. Princeton: Princeton University Press.

Bhagwati, Jagdish and Vivek H. Dehejia. 1994. Freer Trade and Wages of the Unskilled: Is Marx Striking Again? In Jagdish Bahgwati and Marvin H. Koesters (eds). Trade and Wages: Leveling Wages Down?, pp. 36-75. Washington: The American Enterprise Institute Press.

Baker, Andy. 2006. Who Wants to Globalize? Consumer Tastes and Labor Markets in a Theory of Trade Policy Beliefs. American Journal of Political Science, 49: 924-938.

Beaulieu, Eugene, Michael Benarroch, and James Gaisford. 2004. Intra-Industry Trade Liberalization, Wage Inequality and Trade Policy Preferences. Discussion Paper 2004-2006. Department of Economics: University of Calgary.

Berezin, Mabel. 2009. Illiberal Politics in Neoliberal Times. Cambridge: Cambridge University Press.

Besnier, Niko. 1990. Language and Affect. Annual Review of Anthropology, 19: 419-451.

Boix, Carles. 2002. Globalization and the Egalitarian Backlash: Protectionism versus Compensatory Free Trade. Paper prepared for the Workshop on Globalization and Egalitarian Redistribution, Santa Fe Institute, May 17-19.

Caldwell, John. 1976. Toward a Restatement of the Demographic Transition Theory. Population and Development Review, 2: 321-366.

Camerer, Colin F., George Loewenstein, and Matthew Rabin. 2003. Advances in Behavioral Economics. Princeton: Princeton University Press.

Cline, William R. 1989. Macroeconomic Influences on Trade Policy. American Economic Asssociation Papers and Proceedings, 79: 123-127.

Cohen, Michele and Jean-Yves Jaffray. 1980. Rational Behavior under Complete Ignorance. Econometrica, 48: 1281-1299. 
Conlisk, John. 1996. Why Bounded Rationality? Journal of Economic Literature, 34: 669700.

Dohmen, Thomas J., Armin Falk, David Huffman, Juergen Schupp, Uwe Sunde, and Gert G. Wagner. 2006. Individual Risk Attitudes: New Evidence from a Large, Representative, Experimentally-Validated Survey. CEPR Discussion Paper 5517: DIW Berlin.

Eichenberg, Richard and Russell J. Dalton. 1993. Europeans and the European Community: The Dynamics of Public Support for European Integration. International Organization, 47: 507-534.

Ferrera, Maurizio. 1996. The Southern Model of Welfare in Social Europe. Journal of European Social Policy, 6: 17-37.

Fishman, Robert. 2006. Democracy's Voices. Ithaca: Cornell University Press.

Foddy, William. 1993. Constructing Questions for Interviews and Questionnaires. Cambridge: Cambridge University Press.

Gabel, Matthew J. 1998. Interests and Integration: Market Liberalization, Public Opinion, and European Union. Ann Arbor: University of Michigan Press.

Granovetter, Mark. 1985. Economic Action and Social Structure: The Problem of Embeddedness. American Journal of Sociology, 91: 481-510.

Hainmueller, Jens and Michael J. Hiscox. 2006. Learning to Love Globalization: Education and Individual Attitudes to International Trade. International Organization, 60: 469-498.

Hartog, Joop, Ada Ferrer-i-Carbonell, and Nicole Jonker. 2002. Linking Measured Risk Aversion to Individual Characteristics. Kyklos, 55: 3-26.

Hays, Jude C., Sean D. Ehrlich, and Clint Peinhardt. 2005. Government Spending and Public Support for Trade in the OECD: An Empirical Test of the Embedded Liberalism Thesis. International Organization, 59: 473-494.

Hiscox, Michael J. 2006. Through a Glass and Darkly: Attitudes Toward International Trade and the Curious Effects of Issue Framing. International Organization, 60: 755-780.

Irwin, Douglas A. 1994. The Political Economy of Free Trade: Voting in the British General Election of 1906. In Robert C. Feenstra, Gene M. Grossman, and Douglas A. Irwin (eds). The Political Economy of Trade Policy: Papers in Honor of Jagdish Bhagwati, pp. 53-75. Cambridge: MIT Press.

Jacobs, Didier. 1998. Social Welfare Systems in East Asia: A Comparative Analysis Including Private Welfare. Case Paper 10. London: Center for Analysis of Social Exclusion.

Kahnemann, Daniel. 2003. Maps of Bounded Rationality: Psychology for Behavioral Economics. The American Economic Review, 93:1449-1475.

Katzenstein, Peter J. 1985. Small States in World Markets: Industrial Policy in Europe. Ithaca, N.Y: Cornell University Press.

Korpi, Walter and Joakim Palme. 1998. The Paradox of Redistribution and the Strategy of Equality: Welfare State Institutions, Inequality, and Poverty in Western Countries. American Sociological Review, 63: 662-687.

Kuhn, Thomas. 1962. The Structure of Scientific Revolutions. Chicago: University of Chicago Press.

Luce, R. Duncan and Howard Raiffa. 1957. Games and Decisions. New York: John Wiley.

Machina, Mark J. 1989. Dynamic Consistency and Non-Expected Utility Models of Choice Under Uncertainty. Journal of Economic Literature, 27:1622-1668.

Machina, Mark J. 1987. Choice under Uncertainty: Problems solved and Unsolved. Economic Perspectives, 1: 121-154. 
Magee, Stephen P. 1980. Three Simple Tests of the Stolper-Samuelson Theorem. In Peter Oppenheimer (ed). Issues in International Economics, pp. 138-153. London: Oriel Press.

Mansfield Edward D. and Marc L. Busch. 1995. The Political Economy of Non Tariff Barriers: A Cross-National Analysis. International Organization, 49: 723-749.

March, James. 1994. A Primer on Decision Making: How Decisions Happen. New York: Free Press.

Mayda, Anna M. and Dani Rodrik. 2005. Why are some People (and Countries) more Protectionist than Others? European Economic Review, 49: 1393-1430.

Mayer, Frederick W. 1998. Interpreting NAFTA. New York: New York University Press.

Ohlin, Bertil G. 1933. Interregional and International Trade. Cambridge: Harvard University Press.

O' Riain, Seán. 2000. States and Markets in an Era of Globalization. Annual Review of Sociology, 26: 187-213.

O'Rourke, Kevin H. and Richard Sinnott. 2001. The Determinants of Individual Trade Policy Preferences: International Survey Evidence. In Susan M. Collins and Dani Rodrik (eds). Brooking's Trade Forum, pp. 157-196. Washington D.C: Brookings Institution Press.

Payne, Stanley L. 1951. The Art of Asking Questions. Princeton: Princeton University Press.

Polanyi, Karl. 1971. Trade and Market in the Early Empires: Economies in History and Theory. Chicago: Henry Regnery Company.

Quatrone, George A. and Amos Tverski. 1988. Contrasting Rational and Psychological Analyses of Political Choice. American Political Science Review, 85: 23-36.

Rankin, David M. 2002. Identities, Interests, and Imports. Political Behavior, 23: 351-376.

Rodrik, Dani. 1998. Why do more Open Economies have Bigger Governments? Journal of Political Economy, 106: 997-1032.

Rudra, Nita. 2007. Welfare States in Developing Countries: Unique or Universal? The Journal of Politics, 69: 378-396.

Rogowski, Ronald. 1987. Commerce and Coalitions. Princeton: Princeton University Press.

Scheve, Kenneth F. and Matthew J. Slaughter. 2001. What determines Individual Trade Policy Preferences? Journal of International Economics, 54: 267-292.

Simon, Herbert A. 1991. Bounded Rationality in Organizational Learning. Organization Science, 2: 125-134.

Smith, Adam. [1776] 1937. The Wealth of Nations. New York: The Modern Library.

Snow, David A., E. Burke Rochford, Jr., Steven K. Worden, and Robert D. Benford. 1986. Frame Alignment Processes, Micromobilization, and Movement Participation. American Sociological Review, 45: 787-801.

Stolper, Wolfgang F. and Paul A. Samuelson. 1941. Protection and Real Wages. Review of Economic Studies, 9: 58-73.

Takacs, Wendy E. 1985. More on Protectionist Pressure and Aggregate Economic Conditions: A Reply. Economic Inquiry, 23: 183-184.

van Dijk, Teun A. 1984. Prejudice in Discourse: An Analysis of Ethnic Prejudice in Cognition. Amsterdam: John Benjamins.

Wood, Geof and Ian Gough. 2006. A Comparative Welfare Regime Approach to Global Social Policy. World Development, 34: 1696-1712. 


\section{Appendix}

Table A1 Descriptive Statistics for Analysis of Spanish Survey on Frames about Free Trade

Variables Mean (Standard Deviation) or \%

Main Model: $\mathrm{N}=651$

Attitudes to Trade Policy (\% against protection)

Consumer Power (0-10)

$5.7(2.7)$

Age

45.7 (17.4)

Nationalism (1-5; 1=Nationalist)

$3.0(1.4)$

Gender (\% women)

49

Unemployed (\%)

17

Manual Workers (\%)

22

Selection Model: $\mathrm{N}=1008$

No Valid Answer on Attitudes to Trade Policy (\%)

Sources of Political Information (0-8)

Highest Degree (1-6)

$3.7(1.6)$

Source: ASEP (May, 2009).

Note: This variable has been rescaled for presentation purposes. In the analysis the range for this variable is $-2.09-1.65$.

\section{Table A2 Descriptive Statistics for Comparative Analysis of Attitudes to Free Trades}

\begin{tabular}{lc} 
Aggregate Variables & Average (Standard Deviations) \\
\hline Health and Welfare Expenditures per GDP (circa 2003) & $18.2(7.4)$ \\
GDP/per capita in 2003 & $19,768.5(14,478.9)$ \\
Trade Balance/GDP in 2003 (per 10000) & $48.1(903.5)$ \\
Unemployment in 2003 (\%) & $8.8(5.4)$ \\
Years in Gatt/WTO & $38.2(19.0)$ \\
Trade Openness & $64.2(31.0)$ \\
Individual-Level Variables & \\
Attitudes to Trade Policy (\% against protection) & $24.7(10.3)$ \\
Age & $46.1(3.8)$ \\
Gender (\% women) & $53.1(4.9)$ \\
Secondary education (\%) & $38.1(16.8)$ \\
Higher education (\%) & $16.0(7.5)$ \\
Employed (\%) & $57.0(8.1)$ \\
Union member (\%) & $20.3(18.0)$ \\
Extreme Ideological Self-Placement (\%) & $5.7(0.6)$ \\
Nationalism (1-5) & $2.9(0.5)$ \\
Patriotism (1-5) & $4.2(0.3)$ \\
Income (Deciles) & $4.9(0.3)$ \\
Professionals (\%) & $11.8(5.4)$ \\
High Official, Technical, Managers, and Legislators (\%) & $20.3(7.8)$ \\
Clerical Workers (\%) & $20.1(7.0)$ \\
\hline
\end{tabular}

Sources: United Nations Common Database; World Trade Organization; IMF (Government Financial Statistics); ISSP 2003 Dataset. 